\author{
(online) $=$ ISSN $2285-3642$ \\ ISSN-L = $2285-3642$ \\ Journal of Economic Development, Environment and People \\ Volume 9, Issue 2, 2020 \\ url: http://jedep.spiruharet.ro \\ e-mail: office jedep@spiruharet.ro
}

\title{
The Geographic Determinants of Economic Growth and the Increasing Albania-Kosovo Trade Relations
}

\author{
Valbona Mehmeti ${ }^{1}$ \\ Lecturer \\ Faculty of Business, Aleksander Moisiu University of Durres, Albania
}

\begin{abstract}
For the last few years, the trade volume between Albania and Kosovo has increased considerably, clearly showing that, on top of many other factors, the geographic determinants of economic growth and development must never be underestimated. On the other hand, the ever-closer economic integration of Albania and Kosovo is only natural and should not be considered as a cause for political rifts in the Western Balkans. The paper will go through the various documents and agreements adopted by Tirana and Pristina to promote mutual trade relations, and it will refer to an abundance of data indicating improving trade relations. Subsequently, the paper will shed light on the patterns of economic behavior that Albania and Kosovo show, a behavior which can be better comprehended under the framework of geographic determinants of economic growth and development, such as location, resources, food productivity, population and population growth, regionalization, culture, etc.
\end{abstract}

Keywords: economic geography, economic growth, Albania-Kosovo trade, ethnic economies

JEL Codes: 01, 019, 04

How to cite: Mehmeti, V. (2020). The geographic determinants of economic growth and the increasing Albania-Kosovo trade relations. Journal of Economic Development, Environment and People, 9(2). DOI: https://doi.org/10.26458/jedep.v9i2.657

\section{Introduction}

The purpose of this paper is to shed light on the patterns of economic behavior that Albania and Kosovo show, a behavior that can be better explained and comprehended under the framework of geographic determinants of economic growth and development. During the last five years, Albania and Kosovo have grown closer in so far as their trade relations are concerned. The two countries have signed numerous bilateral agreements to lower trade barriers. Furthermore, aware of the very difficult road ahead to full European Union integration, the two countries have turned to themselves, even showing the first glimpses of establishing an Albanian trading bloc.

As of today, more than 5 million Albanians are living in the Balkans. However, their number, the resources they possess, the geographic area they live in never played any significant role in promoting

Valbona Mehmeti, Tel/Fax: +355 52 236373, E-mail: $\underline{\text { mehmeti.valbona@yahoo.com }}$ 


\author{
(online) = ISSN $2285-3642$ \\ ISSN-L = $2285-3642$ \\ Journal of Economic Development, Environment and People \\ Volume 9, Issue 2, 2020 \\ url: http://jedep.spiruharet.ro \\ e-mail: office jedep@spiruharet.ro
}

economic growth or improving their living standards. Albanians in the Balkans never formed a single market, which could have helped enhance their prosperity. However, the independence of Kosovo in 2008 created new possibilities for fostering a bigger market, which could generate greater wealth, even though the expected developments did not happen overnight. During the last five years, the Albania-Kosovo trade relations have grown considerably. Despite the political rhetoric either from Tirana or Pristina, or even from Belgrade, the developments are very much in line with what the experience indicates or the theories uphold. On the one hand, Kosovo has raised the customs tariffs for the goods made in Serbia and, on the other hand, Albania and Kosovo are closely working to eliminate all trade barriers and facilitate greater bilateral exchanges.

There is no dispute that the bigger the markets are, the greater the resources and the population are, the better the geographic position is, the greater are the potentials for economic growth and development. This is the main reason why, throughout history, human societies have struggled to grow bigger. War used to be a means for achieving bigger markets, while now cooperation is the keyword and this trend has some very strong empirical and theoretical footing. To this end, the paper will indicate - by resorting to the facts on the ground and the geographic determinants of economic growth, supported also by the augmented Solow-Swan model of economic growth and the game theory - that the actions undertaken by Albania and Kosovo are fully rational, intending to increase their own benefits.

\title{
2. Theoretical framework
}

Geography plays an important role in either spurring or deterring economic growth and development. The Nobel laureate Paul Krugman $(1991,1999)$ has emphasized that geography - natural resources, access to the sea, transportation, urban development, population growth, production concentration - influences the economic behavior of a society. Another notable study suggests that geographic determinants, such as location, climate, natural resources, food productivity, population and population growth, regionalization, culture, etc., "affect economic policy choices" (Gallup, Sachs, and Mellinger, 1999, p. 179). The contribution that geography - land, soil quality, natural resources, climate, topography - makes towards promoting or preventing economic growth and development was also underlined by Acemoglu (2009).

Taking a cue from geographic determinants of economic growth and development, it is now proven beyond doubt that economic growth and population growth go hand in hand. The Nobel laureate Simon Kuznets, a great economist, and statistician who consolidated the empirical nature of economics proved the positive relationship between economic growth and population growth. Throughout human history, even before industrialization, "the population of several countries grew and enjoyed a rising per capita product" (Kuznets, 1967, p. 170). Later studies have now led to a wide consensus that a bigger population offers a better chance for greater economic growth and wealth, looking at people as the best factor for ensuring development (Simon, 1994, 1998). A bigger population means a bigger labor force, more brainpower, and more educated people "who will exert their wills and imaginations for their own benefit, and so inevitably they will benefit not only themselves but the rest of us as well" (Simon, 1994, p. 29).

A study conducted by Nicholas G. Mankiw, David Romer, and David N. Weil serve as the foundation for the growth model which takes into consideration the human capital. In fact, that would be the Solow-Swan economic growth model, which is in a way augmented by the addition of the human capital into the formula (Mankiw, Romer and Weil, 1992). They observe that "the augmented Solow model provides an 


\author{
(online) = ISSN $2285-3642$ \\ ISSN-L = $2285-3642$ \\ Journal of Economic Development, Environment and People \\ Volume 9, Issue 2, 2020 \\ url: http://jedep.spiruharet.ro \\ e-mail: office jedep@spiruharet.ro
}

almost complete explanation" to economic growth and development (Mankiw et al., 1992, p. 408). This model was further augmented with the inclusion of other human-related factors, such as health, longevity, education (Knowles and Owen, 1995).

If we are, to put it differently, a bigger population means a bigger market, and human societies have always striven to become bigger. Since time immemorial, markets have tended to expand and enlarge. At the end of the day, almost all wars, throughout human history, have been waged for economic reasons (Howerth, 1916). As centuries went by, the war started to become somewhat obsolete, but the resolve of the markets to grow bigger is still there. To a greater extent, cooperation has taken the place of wars. Especially after World War II, countries have chosen to merge their markets to give themselves greater opportunities. In 1944, Belgium, Luxemburg, and the Netherlands choose to establish the Benelux Union, while the very first traces of the European Union are to be found in 1957, when Belgium, France, Germany, Italy, Luxembourg, and the Netherlands established the European Economic Community in the form of a common market and customs union. In 1960, four other small European countries - Iceland, Liechtenstein, Norway, and Switzerland - established the European Free Trade Association. Such examples are also to be found in other regions of the world: the Economic Community of West African States in Africa, the Economic Cooperation Organization in Asia, the Latin American and Caribbean Economic System, and the Central American Integration System in Latin America, etc. The Central European Free Trade Agreement is also another example of such cooperation trends, bringing together Western Balkans countries and Moldova. The theoretical foundation behind such cooperation initiatives was offered in 1944 by the mathematician John von Neumann and the economist Oskar Morgenstern.

In a ground-breaking work, they presented and consolidated their 'game theory', a theory which attempts to create models and to predict the outcome of a conflict between rational individuals (Von Neumann and Morgenstern, 1953). In a nutshell, the game theory may be defined as "the study of mathematical models of conflict and cooperation between intelligent rational decision-makers" (Myerson, 1997, p. 1) and, from this point of view, the notion of 'game' represents any "event where people interact" (Drechsel, 2010, p. 5). The types of games are many and they are divided into two main groups: noncooperative games and cooperative games. In all kinds of situations, the intelligent rational decision-makers compete and all of them try to benefit the most from the situation, or the game, but in case of noncooperative games they do not know each other's actions and in case of cooperative games they are aware and know each other's actions and they form coalitions.

\title{
3. Facts on the ground: Albania-Kosovo economic relations
}

\subsection{Albania-Kosovo relations: The cooperative game}

In so far as the present situation and economic behaviors of Albania and Kosovo are concerned, the cooperative game is the type that applies best. Of course, both countries are independent rational competing players, but they have come to realize that cooperation serves their interests much better than non-cooperation. Thus, forming a coalition is more fruitful than fighting each other.

Albania and Kosovo are two independent Balkan countries inhabited by the same ethnic group, sharing the very same language, culture, and history. The whole region inhabited by Albanians used to be part of 


\author{
(online) = ISSN $2285-3642$ \\ ISSN-L = $2285-3642$ \\ Journal of Economic Development, Environment and People \\ Volume 9, Issue 2, 2020 \\ url: http://jedep.spiruharet.ro \\ e-mail: office jedep@spiruharet.ro
}

the Ottoman Empire and, at the end of World War I, for various geopolitical reasons only one part of it was recognized as an independent country, and that was Albania. Other Albanian-inhabited territories were made part of Yugoslavia. As of now, since Yugoslavia no longer exists, some of the Albanian-inhabited territories are part of Montenegro and North Macedonia. Kosovo was another of those Albanian-inhabited territories which used to be part of Serbia. After the 1999 internal conflict in Serbia, Kosovo was put under the administration of the United Nations and, in 2008, declared its independence.

This particular reality of 'one people, two countries' makes it much easier for Albania and Kosovo to cooperate with each other. In 2009, Albania finalized its biggest public infrastructure project. At the cost of almost 1 billion euros, Albania built a new 180 kilometers long highway from the coastal and port city of Durres to the border with Kosovo. In 2013, Kosovo also finalized the almost 100 kilometers long new highway from the capital city Pristina to the border with Albania. Today, more than 1.8 million vehicles per year travel the Albania-Kosovo highway.

Serbia has not recognized Kosovo's independence and, in fact, tries as much as possible to hinder its sovereignty, economic development, and prosperity of its people. This has made Kosovo grow further apart from Serbia, further apart from trading with the ex-Yugoslavia countries, and to forger even closer cooperation with Albania.

\title{
3.2 Albania-Kosovo bilateral agreements
}

Since 2014, the governments of Albania and Kosovo have held regular annual joint meetings and both countries have signed numerous agreements, memoranda and protocols, mainly focused on promoting greater bilateral trade relations.

Kosovo is a landlocked country and having access to the Adriatic Sea and the Albanian ports is of vital and strategic importance. The greater part of the goods imported by Kosovo goes transit through Albania. On the other hand, the Albanian market is important for the agricultural and other food products made in Kosovo. In so far as Albania is concerned, Kosovo provides the main source of income for the local tourism industry, as well as an important market for construction materials, minerals, electricity, fuel, etc.

The first step was the 2003 free trade agreement between Albania and Kosovo. However, the efforts grew bolder especially after Kosovo declared its independence in 2008. A lot has changed since then. As of now, Albania and Kosovo have signed almost 50 different agreements, a third of which is concerned with promoting wider market integration and greater mutual trade relations.

Albania and Kosovo have now established joint border checkpoints, which have served to greatly facilitate the movement of goods and people. Albanian citizens do not need passports to travel to Kosovo and there is no time limit to their stay there, and the same is true for the Kosovo citizens traveling to Albania. The Kosovo citizens do not need any particular permits in order to work, reside, or do business in Albania, and the same will apply soon to the Albanian citizens in Kosovo.

Since the end of 2018, under a special agreement, any public document issued in Kosovo is fully and automatically recognized in Albania to bear the same value, and the same applies to any public document issued in Albania. This has helped promote bilateral trade, especially the import and export of goods accompanied by various certificates, such as a certificate of origin, certificate of quality, health certificate, veterinary certificate, phytosanitary certificate, etc. 


\author{
(online) = ISSN $2285-3642$ \\ ISSN-L = $2285-3642$ \\ Journal of Economic Development, Environment and People \\ Volume 9, Issue 2, 2020 \\ url: http://jedep.spiruharet.ro \\ e-mail: office jedep@spiruharet.ro
}

The Kosovo Customs has established an office at the port of Durres, in Albania, which serves now as an entry point for goods destined for Kosovo. Furthermore, both countries intend to fully demolish any notion of the border between them, thus emulating the internal borders among European Union member countries.

\title{
3.3 The growing Albania-Kosovo trade
}

Albania has a population of almost 2.9 million, 72.4 percent of which is younger than 54 years old (Institute of Statistics, 2019a), and Kosovo has a population of about 1.8 million, 84.8 percent of which is younger than 54 years old (Kosovo Agency of Statistics, 2018). The nominal 2019 Gross Domestic Product of Albania was at almost 15.4 billion dollars, whereas the nominal 2019 Gross Domestic Product of Kosovo was at 7.9 billion dollars (International Monetary Fund, 2019). The Kosovo international trade balance is highly negative: during 2019, the exports were at about 383.5 million euros and imports were at almost 3.5 billion euros (Kosovo Agency of Statistics, 2020). Albania represents the same outlook, too. During 2019, the exports were at about 2.45 billion euros and imports were at 5.3 billion euros (Institute of Statistics, 2020).

Both countries are hugely dependent on imports and increasing bilateral exchange is a way to boost their respective economies. In 2018, Kosovo imposed higher customs tariffs on goods made in Serbia. On average, Kosovo applies a customs tariff of 10 percent on the price of the imported goods. At first, Kosovo imposed an increase of 10 percent over the normal customs tariff for the goods originating from Serbia and by the end of 2018 imposed an increase of 100 percent. For the 2005-2018 period, the Serbian exports towards Kosovo amounted to an average of almost 257 million euros per year (Gashi and Berisha, 2019). However, after the customs tariff increase, the Serbian exports towards Kosovo fell by 98.5 percent (Gashi and Berisha, 2019). Subsequently, the same trend applied also to the Kosovo exports towards Serbia, which fell drastically from an average of 18 million euros per year over the period before 2018.

The aggressive promotion of Albania-Kosovo trade relations served to fill the gap, even though such relations had started to gradually improve since 2008. The 2016 exports of Albania towards Kosovo amounted to about 136 million euros (Institute of Statistics, 2018), whereas in 2019 they were at 244 million euros (Institute of Statistics, 2020). During that same period, from 2016 to 2019, the Kosovo exports towards Albania grew by almost 30 percent, even though their gross value is smaller than the imports from Albania. The Kosovo exports towards Albania for 2019 amounted to about 73 million euros.

Kosovo is renowned as a food producer and the food exports towards Albania are increasing steadily, whereas Albania is exporting mainly construction materials, electricity, and fuel.

\subsection{Albania-Kosovo economic relations beyond the simple trade}

However, to narrow down the whole economic relations between Albania and Kosovo merely to the goods imported and exported between them would not be the right approach.

Albania was founded in 1912 and Yugoslavia in 1918, part of which was also Kosovo. The two Balkan countries, Albania and Yugoslavia, never had any good relations, and this made Albania and Kosovo grow 


\author{
(online) = ISSN $2285-3642$ \\ ISSN-L = $2285-3642$ \\ Journal of Economic Development, Environment and People \\ Volume 9, Issue 2, 2020 \\ url: http://jedep.spiruharet.ro \\ e-mail: office jedep@spiruharet.ro
}

into different directions. Being a country with wide access to the Adriatic Sea and the Ionian Sea, Albania sought its economic exchanges mostly in the regions of the Mediterranean Sea. On the other hand, Kosovo became entirely connected and totally dependent on Serbia for everything. This is the reason why Kosovo, even after declaring its independence in 2008, maintained rather strong and vast economic relations with Serbia, whereas the trade relations with Albania were very sluggish to take off. Studies conducted have emphasized that the "long isolation and lack of communication between the two societies is still casting its shadow on the new emerging relations between Albania and Kosovo, making them somehow difficult" (Sulcebe, 2015, p. 12).

Serbia has never recognized Kosovo's independence and this has made Kosovo seek new alternatives to promote growth and development. Getting closer to Albania was only natural. Everything was right for the two countries to assist each other, to cooperate closely and trade more with each other. The two countries are made up of the same people, sharing the very same language, culture, and history. Things changed for better after 1999 when the Serbian province of Kosovo was put under the administration of the United Nations, and especially after 2008 when Kosovo declared its independence. The two countries, since their respective governments started holding annual joint meetings, have also laid down a sort of roadmap to harmonize their institutional and legal frameworks. The end objective is unifying the two markets in the form of a customs union or a single market, much like the Benelux Union or European Union.

\title{
4. Role of geography in the Albania-Kosovo economic cooperation
}

There is no denying that geography has played a significant role in stimulating the ever-increasing economic cooperation and trade relations between Albania and Kosovo. Each geographic determinant of economic growth and development has its own part in ensuring greater cooperation.

First of all, looking at it from a cultural perspective, it is the population of both countries which serves as an important promoting factor. Both countries, Albania and Kosovo, are inhabited by Albanians. In this context, it is much easier for both people and societies to relate to each other, to communicate, to cooperate and, therefore, trade. The population of both countries shares the same language, culture, and history. This means that both societies can interact very easily, without any underlying fears or biases, and this makes doing business so much more effective.

Looking at it in terms of numbers and size of the market, the population of both countries creates a growth synergy which is far greater than the simple sum of the individual parts. The changing and growing interaction of the population of both countries brings about the synergy effect (Holubcik and Soviar, 2016), which subsequently produces more value and prosperity. Albania and Kosovo are a market of almost 5 million people, and it will prosper better if acting as one rather than two separate parts.

The tourism sector, which is very important for Albania's economy, is an excellent example. During 2018, about 5.9 million tourists visited Albania and more than 2 million of them originated from Kosovo (Institute of Statistics, 2019b). This means that the whole of Kosovo's population chose to spend their summer holidays in Albania. They could have gone anywhere else, but they decided that they were better welcomed, served, and appreciated in Albania. On the other hand, tourists from Albania traveling abroad during 2018 spent more than 1.4 billion euros and 13 percent of them choose Kosovo as their holiday 


\author{
(online) = ISSN $2285-3642$ \\ ISSN-L = $2285-3642$ \\ Journal of Economic Development, Environment and People \\ Volume 9, Issue 2, 2020 \\ url: http://jedep.spiruharet.ro \\ e-mail: office jedep@spiruharet.ro
}

destination (Institute of Statistics, 2019b). At first sight, this may not seem very significant, especially if compared to the number of Albanian tourists traveling to Greece or Italy, but it is of great importance since a few years back there were no tourists from Albania going to Kosovo.

The respective geographic positions of Albania and Kosovo help facilitate the increasing relations. Both countries complement each other, stretching from the coasts of the Adriatic Sea and the Ionian Sea towards the hinterlands of the Balkan Peninsula on the east. The Albania-Kosovo highway will soon stretch towards Serbia, in Nish, in order to connect to the European Corridor X, running from Salzburg in Austria to Thessaloniki in Greece. The highway has now become the main facility linking Kosovo with the international markets. During 2019, more than 4 million tons of different goods went through the port of Durres in Albania, and more than 10 percent of them were goods imported or exported by Kosovo. This amount was twice of that registered in 2018 (Shala, 2020). Kosovo is also using Albania as the transit route for its supply of fuels, exploiting the port of Porto Romano for that purpose, which is a bunkering port specialized in importing and exporting fossil fuels. Since last year, the Kosovo Customs has established offices at the port of Durres and the port of Porto Romano, in Albania, thus facilitating, even more, the movement of goods and the import/export activities. On the other hand, in so far as Albania is concerned, closer cooperation with Kosovo means easier access to the inward markets of the Balkan Peninsula, as well as access to the vast producing capacity of the Kosovo agriculture.

The combination of natural resources of both countries makes closer cooperation even more profitable. Electric energy generation is a good example. Albania is by far richer than Kosovo in water resources, especially rivers, which are exploited for generating electric energy. During the rainy seasons, Albania can even export some amounts of electric energy, but it is forced to import rather great amounts during dry seasons, and the price difference is huge. During the early months of 2019, Albania imported electric energy at the price of almost 73 euro/MWh, however, the export price during that period was not higher than 58 euro/MWh ("Importi i energjise", 2019). Apart from that, a sizeable portion of the import or export price goes to transmission costs paid to other countries or their companies. On the other hand, Kosovo is totally dependent on coal-fired power plants. Almost 97 percent of the electric energy produced in Kosovo is generated from two coal-fired power plants (Beer, Mielczarski and Taylor, 2012). Kosovo holds some of the greatest lignite reserves in the world, and now is planning to build new and modern coal-fired power plants. The electric energy production in Kosovo is far more stable than that of Albania, this is the reason why Albania and Kosovo signed an agreement to establish a common electric energy market and join their power distribution grids. In this way, both countries take advantage of each other's natural resources and developing potentials. Studies have shown that cross-border electric energy trade or exchange is by far more convenient and advantageous (Antweiler, 2016).

Access to sea is one of the greatest geographic determinants of economic development. Being a landlocked country, Kosovo finds in Albania the much-needed access to international trade routes. Sea transport is a lot more efficient and cost-effective. Studies have underlined that, among other geographic determinants, the ability of a country to have access to the sea "can crucially affect transport costs and the extent of its integration with the world" (Osang, 2006, p. 35).

\title{
5. Conclusion: The power of place
}




\author{
(online) = ISSN $2285-3642$ \\ ISSN-L = $2285-3642$ \\ Journal of Economic Development, Environment and People \\ Volume 9, Issue 2, 2020 \\ url: http://jedep.spiruharet.ro \\ e-mail: office jedep@spiruharet.ro
}

There is no arguing that geography influences the economic behavior of a society. The geographic determinants of economic development and growth are there, even though sometimes they are hard to identify or sometimes we take them for granted. If we are to refer to a book written by De Blij (2009), the role of geography in economic development is viewed as the power of place, whereas Schwarz (2008) holds that "geography is destiny".

Subsequently, whatever is going on between Albania and Kosovo now, whatever steps the two countries and societies take to grow closer and to integrate their economies, even more, is only natural taking into consideration the geographic factors they share.

Albania and Kosovo are inhabited by the same people, speaking the same language, sharing the same history, having the same culture and beliefs. So, it is expected and, normally, they would want to cooperate more with each other, just as they are doing now. In the same manner, because of their location, their vicinity and access to the sea, their climate and their natural resources, Albania and Kosovo find it easier and more advantageous to cooperate with each other.

Even though regional and international politics and powers to be might not feel very comfortable with such close economic cooperation and rapprochement between Albania and Kosovo, since, putting it bluntly, they are two Albanian countries, it is impossible to dispute the power of place.

\title{
6. References
}

[1] Acemoglu, D. (2009). Introduction to modern economic growth. Princeton, NJ: Princeton University Press.

[2] Antweiler, W. (2016). Cross-border trade in electricity. Journal of International Economics, 101, 42-51. DOI: http://dx.doi.org/10.1016/j.jinteco.2016.03.007

[3] Beer, Janos M., Mielczarski, W., and Taylor, D. M. (2012). Kosovo: Kosovo Power Project. Washington, DC: World Bank Group.

[4] De Blij, H. (2009). The power of place: Geography, destiny, and globalization's rough landscape. Oxford: Oxford University Press.

[5] Drechsel, J. (2010). Cooperative lot sizing games in supply chains. Heidelberg: Springer-Verlag.

[6] Gallup, J. L., Sachs, J. D., and Mellinger, A. D. (1999). Geography and economic growth. International Regional Science Review, 22(2), 179-232. DOI: https://doi.org/10.1177/016001799761012334

[7] Gashi, P., and Berisha, B. (2019). The impact of $100 \%$ tariff on the import of goods from Serbia and Bosnia and Herzegovina. Hamburg: GFA Consulting Group. DOI: https://doi.org/10.13140/RG.2.2.28941.38885

[8] Holubcik, M., and Soviar, J. (2016, October). The growing importance of synergy effect in business environment. Proceedings - Research Track of the 6th Biannual CER Comparative European Research Conference (pp. 8-11). London: Sciemcee Publishing.

[9] Howerth, I. W. (1916). The causes of war. The Scientific Monthly, 2(2), 118-124. Retrieved from https://www.jstor.org/stable/6227

[10] Importi i energjise, OSHEE prokuron 100 milione euro per 5 muajt e ardhshem. (2019, May 11). Retrieved from http://energjia.al/2019/05/11/importi-i-energjise-oshee-prokuron-100-milione-euro-per-5-muajt-e-ardhshem 


\author{
(online) = ISSN $2285-3642$ \\ ISSN-L = $2285-3642$ \\ Journal of Economic Development, Environment and People \\ Volume 9, Issue 2, 2020 \\ url: http://jedep.spiruharet.ro \\ e-mail: office jedep@spiruharet.ro
}

[11] Institute of Statistics. (2018). Foreign trade in goods: December 2017. Tirana: INSTAT.

[12] Institute of Statistics. (2019a). Population in Albania: 1 January 2019. Tirana: INSTAT. Retrieved from http://www.instat.gov.al/media/5154/population-of-albania-first-january-2019.pdf

[13] Institute of Statistics. (2019b). Tourism in figures: Albania 2019. Tirana: INSTAT.

[14] Institute of Statistics. (2020). Foreign trade in goods: December 2019. Tirana: INSTAT.

[15] International Monetary Fund. (2019). World economic outlook database: October 2019 edition. Retrieved from https://www.imf.org/external/pubs/ft/weo/2019/02/weodata/index.aspx

[16] Knowles, S., and Owen, P. D. (1995). Health capital and cross-country variation in income per capita in the Mankiw-Romer-Weil model. Economics Letters, 48(1), 99-106.

[17] Kosovo Agency of Statistics. (2018). Kosovo in figures, 2017. Pristina: KAS. Retrieved from http://ask.rksgov.net/media/4404/kosovo-in-figures-2017.pdf

[18] Kosovo Agency of Statistics. (2020). Kosovo international trade statistics: December 2019. Pristina: KAS.

[19] Krugman, P. (1991). Increasing returns and economic geography. Journal of Political Economy, 99(3), $483-499$.

[20] Krugman, P. (1999). The role of geography in development. International Regional Science Review, 22(2), 142161. DOI: https://doi.org/10.1177/016001799761012307

[21] Kuznets, S. (1967). Population and economic growth. Proceedings of the American Philosophical Society, 111(3), 170-193. Retrieved from http://www.jstor.org/stable/985714

[22] Mankiw, N. G., Romer, D., and Weil, D. N. (1992). A contribution to the empirics of economic growth. The Quarterly Journal of Economics, 107(2), 407-437. DOI: https://doi.org/10.2307/2118477

[23] Myerson, R. B. (1997). Game theory: Analysis of conflict. Cambridge, MA: Harvard University Press, 1997.

[24] Osang, T. (2006, October). External and internal determinants of development. In J. F. Hollifield, P. M. Orrenius and T. Osang (Eds.). Proceedings of the 2006 Conference on Migration, Trade, and Development (pp. 35-59). Dallas, TX: Federal Reserve Bank of Dallas. Retrieved from https://www.dallasfed.org/research/pubs/migration/

[25] Shala, B. (2020, January 14). Dyfishohet perpunimi i mallrave nga porti i Durresit drejt Kosoves. Koha. Retrieved from https://www.koha.net/arberi/203585/dyfishohet-perpunimi-i-mallrave-nga-porti-i-durresit-drejt-kosoves/

[26] Simon, J. L. (1994). More people, greater wealth, more resources, healthier environment. Economic Affairs, 14(3), 22-29.

[27] Simon, J. L. (1998). The ultimate resource 2 (Rev. ed.). Princeton, NJ: Princeton University Press.

[28] Sulcebe, D. (2015). Albania and Kosovo: In quest of a common future. Tirana: Friedrich-Ebert-Stiftung.

[29] Schwarz, B. (2008, December). Geography is destiny. The Atlantic, 161(10). Retrieved from https://www.theatlantic.com/magazine/archive/2008/12/geography-is-destiny/307163/

[30] Von Neumann, J., and Morgenstern, O. (1953). Theory of games and economic behavior (3rd ed.). Princeton, NJ: Princeton University Press. 